\title{
MANAJEMEN PEMBIAYAAN PENDIDIKAN TERHADAP MUTU SEKOLAH MENENGAH KEJURUAN
}

\author{
EDUCATION FINANCING MANAGEMENT ON QUALITY OF VOCATIONAL \\ SCHOOL
}

\author{
Dedy Achmad Kurniady, Linda Setiawati, Siti Nurlatifah \\ Universitas Pendidikan Indonesia, Indonesia \\ dedy_achmad@upi.edu
}

\begin{abstract}
ABSTRAK
Berbicara mengenai mutu pendidikan, akan berkaitan langsung dengan peran sekolah sebagai lembaga pendidikan. Pengelolaan belajar mengajar di sekolah sangat berarti dalam menentukan keberhasilan siswa. Untuk mencapai mutu sekolah yang baik, biaya pendidikan harus dikelola dengan optimal. Oleh karena itu, tahapan pada manajemen pembiayaan pendidikan perlu diperhatikan. Pada dasarnya tujuan manajemen pembiayaan pendidikan adalah terselenggaranya proses pendidikan yang sesuai dengan kebutuhan belajar peserta didik yang diharapkan. Manajemen pembiayaan pendidikan di SMK berada pada kategori sangat tinggi, artinya kepala sekolah pada SMK telah mampu melaksanakan manajemen pembiayaan pendidikan secara maksimal mulai dari perencanaan pembiayaan dan penganggaran, implementasi pembiayaan, pengawasan dan pengendalian pembiayaan dan pertanggung jawaban atau akuntabilitas.
\end{abstract}

Kata Kunci: Manajemen Pembiayaan Pendidikan, Mutu Sekolah

\section{ABSTRACT}

Talking about the quality of education, will be directly related to the role of the school as an educational institution. Management of teaching and learning in schools is significant in determining the success of students. To achieve a good quality of schools, the cost of education should be managed optimally. Therefore, the steps in the management of education financing need to be considered. Basically the purpose of management education financing is the implementation process of education according to the needs of learners expected. Management of financing vocational education is at a very high category, meaning the head of the vocational school has been able to carry out the management of education financing to the maximum ranging from financial planning and budgeting, implementation, financing, monitoring and control of financing and liability or accountability.

Keywords: Educational Financing Management, School's Quality

\section{PENDAHULUAN}

Pendidikan merupakan salah satu aspek terpenting dalam meningkatkan suatu pembangunan negara. Namun, masih terdapat beberapa masalah terkait dengan penyelenggaraan pendidikan yaitu dalam hal pemerataan, relevansi, efisiensi dan mutu pendidikan.

Berbicara mengenai mutu pendidikan, akan berkaitan langsung dengan peran sekolah sebagai lembaga pendidikan. Pengelolaan belajar mengajar di sekolah sangat berarti dalam menentukan keberhasilan siswa. Dalam hal ini sekolah berperan penting dalam menciptakan siswa yang memiliki Jurnal Penelitian Pendidikan pengetahuan, keterampilan serta memiliki nilai religius dan nilai sosial yang tinggi. Dengan demikian sekolah adalah agen sosial yang harus diperhatikan dalam hal proses pembelajarannya.

(Santoso \& Budi, 2014) menyatakan bahwa pendidikan yang bermutu dilihat dari sisi input, proses, output maupun outcome. Input pendidikan yang bermutu adalah guru-guru yang bermutu, peserta didik yang bermutu, kurikulum yang bermutu, fasilitas yang bermutu, dan berbagai aspek penyelenggara pendidikan yang bermutu. Proses pendidikan yang bermutu adalah proses pembelajaran yang bermutu. Output 
pendidikan yang bermutu adalah lulusan yang memiliki kompetensi yang disyaratkan.

Dan outcome pendidikan yang bermutu adalah lulusan yang mampu melanjutkan ke jenjang pendidikan lebih tinggi atau terserap pada dunia usaha atau dunia industri.

Selain dari pada itu kualitas sekolah juga dapat dinilai dari mutu proses, dimana guru memiliki peran yang sangat penting dalam meningkatkan mutu proses pembelajaran. Mengutip dari penelitian menyatakan bahwa 63\% guru SMK tidak memiliki kompetensi profesional standar yang disyaratkan."

Menurut data badan pusat statistik angka putus sekolah pada tahun 2015 usia 7-12 tahun mencapai 0,67\% atau 182,773 anak; anak 1315 tahun sebanyak 2,21\% atau 209,976 anak; dan usia 16-18 tahun mencapai 3,14 persen atau 223,676 anak. Apabila melihat data tersebut maka angka putus sekolah tertinggi ada pada usia 16-18 tahun atau setara pada tingkat SMK sederajat.

Sedangkan mutu outcome pada jenjang SMK masih mewarnai rendahnya mutu sekolah atau pendidikan di Indonesia Badan Pusat Statistik (BPS) menyampaikan tingkat pengangguran terbuka (TPT) pada Agustus 2015 mencapai 7,56 juta orang atau bertambah 320 ribu orang terhadap Agustus 2014. Pengangguran paling banyak terjadi pada lulusan sekolah menengah kejuruan (SMK). Berdasarkan data BPS, tingkat pengangguran terbuka (TPT) SMK mencapai 12,65 persen dari total jumlah pengangguran. Jumlah pengangguran SMK bahkan terus meningkat jika dibandingkan dengan periode Agustus 2014 yang sebesar 11,24 persen dan Februari 2015 9,05 persen. Sedangkan di urutan kedua, jumlah pengangguran paling banyak ditempati lulusan sekolah menengah atas (SMA) sebesar 10,32 persen.
Kemudian secara berturut-turut diikuti lulusan diploma I/III 7,54 persen, universitas 6,40 persen, sekolah menengah pertama 6,22 persen dan sekolah dasar ke bawah 2,74 persen. (Republika, 2015)

Sistem kendali mutu dan jaminan kualitas mutu pendidikan menjadi isu yang utama dalam kontek pendidikan saat ini. Mutu pendidikan yang kasat mata tentunya tertuju pada mutu lulusan dari pendidikan itu sendiri. Untuk dapat menghasilkan lulusan yang bermutu tentunya harus didukung oleh sebuah proses yang sesuai dengan kebutuhan belajar peserta didik, dan tentunya harus didukung oleh faktor-faktor penunjang proses pendidikan yang bermutu pula.

Menurut (Hoy \& Miskel, 2008), banyak faktor yang mempengaruhi mutu sekolah diantaranya budaya organisasi, kepemimpinan kepala sekolah, iklim organisasi, sarana-prasana, kinerja guru, dan pembiayaan.

Biaya dan mutu, merupakan variable yang mempunyai keterkaitan secara langsung dalam menjalankan proses pendidikan yang sesuai dengan kebutuhan belajar peserta didik di jenjang sekolah menengah kejuruan. Menurut (Morphet, 1983), "biaya pendidikan memberikan pengaruh yang positif melalui faktor kepemimpinan dan manajemen pendidikan dan tenaga pendidikan yang kompeten dalam meningkatkan pelayanan pendidikan melalui peningkatan mutu.".

Saat ini, sumber pembiayaan yang diperoleh SMK, sangat beragam, ada yang murni dari dana Bantuan Operasional Sekolah (BOS), dan iuran dari masyarakat berupa SPP, bagi sekolah yang tidak mau menerima BOS. Bagi SMK yang menerima dana BOS, pada SMK per siswa pertahun adalah sebesar Rp. 1.400.000,- 
Dana tersebut memiliki aturan baku yang dibuat oleh pemerintah guna mengatur alokasi dana. Hal ini pula yang menuntut kepala sekolah selaku pengambil keputusan harus dapat melakukan fungsi manajemennya terhadap pembiayaan sekolah secara optimal.

Untuk mencapai mutu sekolah yang baik, biaya pendidikan harus dikelola dengan optimal. Oleh karena itu, tahapan pada manajemen pembiayaan pendidikan perlu diperhatikan. Pada dasarnya tujuan manajemen pembiayaan pendidikan adalah terselenggaranya proses pendidikan yang sesuai dengan kebutuhan belajar peserta didik yang diharapkan. Pada setiap proses tahapan manajemen pembiayaan perhatian utamanya adalah pencapaian visi dan misi sekolah. Tahapan manajemen pembiayaan pendidikan melalui tahapan perencanaan pembiayaan pendidikan, tahapan pelaksanaan pembiayaan, dan pengawasan pembiayaan pendidikan.

\section{METODE PENELITIAN}

Desain dalam penelitian ini dimulai dari melakukan studi pendahuluan untuk mengidentifikasi dan menentukan masalah. Setelah itu, masalah diidentifikasi untuk menentukan variabel penelitian. Penentuan variabel penelitian dilakukan dengan melakukan studi kepustakaan yang relevan agar penentuan variabel dapat sesuai dengan permasalahan yang sedang terjadi yang setelahnya dirumuskan ke dalam latar belakang masalah yang didalamnya menggambarkan fenomena-fenomena yang terjadi terkait permasalahan yang akan menjadi tujuan penelitian. Selanjutnya dibuat rumusan masalah berupa pertanyaanpertanyaan yang harus dapat terjawab dalam penelitian ini. Kemudianpenelitimerumuskan kerangka konseptual dan hipotesis awal. Selanjutnya peneliti menentukan metode dan pendekatan penelitian yang akan digunakan untuk mendapatkan data yang diperlukan. Peneliti menggunakan angket/kuesioner untuk mendapatkan data yang diperlukan. Setelah data terkumpul peneliti selanjutnya melakukan analisis dan pengolahan data dengan menggunakan perhitungan statistika untuk melakukan pengujian hipotesis yang telah dituliskan. Setelah melakukan analisis dan pengolahan data peneliti baru dapat menyusun temuan serta pembahasan dari hasil pengolahan data yang telah dilakukan yang menjadi jawaban dari rumusan masalah. Kemudian dari temuan dan pembahasan tersebut dapat ditarik kesimpulan serta rekomendasi dari masalah yang terdapat dari hasil pengolahan data dari penelitian yang dilakukan sebagai feedback dari peneliti bagi lembaga yang diteliti.

PopulasidalampenelitianiniadalahKepala Sekolah SMK di Kota Bandung sebanyak 134 orang. Kemudian diambil sample dengan menggunakan teknik Probability Sampling melalui Simple Random Sampling dengan hasil sebanyak 32 responden.

Instrumen yang digunakan dalam penelitian ini yaitu angket. Kuisioner/ angket adalah suatu teknik pengumpulan data yang dilakukan dengan membuat sejumlah pertanyaan atau pernyataan yang kemudian disebar kepada responden untuk mendapatkan jawabannya. Sugiono (2013, hlm 199).

Setelah instrumen disebar dan diperolh data kemudian data yang didapat diseleksi untuk dapat mengetahui apakah data tersebut layak diolah atau tidak, setelah penyeleksia data, langkah selanjutnya yaitu 
pengklasifikasian data yaitu mengumpulkan angket yang didapat dari seluruh responden berdasarkan variabel penelitian yakni variabel $\mathrm{X}$ (Manajemen Pembiayaan Pendidikan) dan variabel Y (Mutu Sekolah). Kemudian ditentukan skor penilaian dari setiap alternatif jawaban yang diberikan sesuai dengan kriteria yang terlah ditentukan oleh skala likert, dan terakhir yaitu melakukan pengolahan data dengan: menghitung kecenderungan umum skor responden dari perhitungan rata-rata, uji normalitas serta distribusi data, uji korelasi, uji koefisien determinasi, uji gisnifikansi korelasi, serta analisis regresi.

\section{HASIL DAN PEMBAHASAN}

Biaya memiliki cakupan yang luas, yaitu semua jenis pengeluaran yang berkenaan dengan penyelenggaraan pendidikan. Manajemen keuangan dan pembiayaan merupakan salah satu sumber daya yang secara langsung menunjang efektivitas dan efisiensi pengelolaan pendidikan. Manajemen pembiayaan pada dasarnya merupakan bagian dari pembiayaan pendidikan yang tercermin dari anggaran yang ditetapkan sekolah.

Menurut (Fattah, 2009), "proses manajemen pembiayaan sekolah adalah Perencanaan Pembiayaan dan Penganggaran, Implementasi Pelaksanaan Pembiayaan, Pengawasan dan Pengendalian, dan Pertanggungjawaban atau Akuntabilitas."

Berdasarkan temuan yang diperoleh dari hasil analisis data penelitian pada Manajemen Pembiayaan Pendidikan pada SMK, menggambarkan hasil rata-rata sebesar 4,65 yang berada pada kategori sangat tinggi. Hal tersebut terukir dari skor rata-rata dimensi Perencanaan Pembiayaan dan penganggaran sebesar 4.57, Dimensi Implementasi Pelaksanaan Pembiayaan sebesar 4.56, Dimensi Pengawasan dan Pengendalian sebesar 4.62, dan Dimensi Pertanggung jawaban/akuntabilitas sebesar 4.84 .

Dalam bidang pendidikan, mutu meliputi input, process, output dan outcome. Input pendidikan yang bermutu adalah segala sesuatu yang mampu diproses oleh sistem pendidikan. Process pendidikan yang bermutu dapat terlihat jika sistem pendidikan yang dilaksanakan mampu memberikan kontribusi yang aktif, kreatif dan memiliki makna bagi terciptanya tujuan pendidikan.

Selain itu, Ali (2007, hlm 361) menyatakan "faktor-faktor strategik yang mempengaruhi mutu pendidikan, yaitu kurikulum/ proses belajar mengajar, manajemen sekolah, oganisasi/ kelembagaan sekolah, fasilitas/ sarana prasarana, guru, pembiayaan, peserta didik, peran serta masyarakat, dan kultur sekolah." Mutu pendidikan dalam penelitian ini melihat kualitas pendidikan dari mutu siswa, mutu guru, lingkungan belajar, disiplin sekolah, kesediaan sumber belajar, partisipasi orang tua, satuan biaya.

Berdasarkan temuan yang diperoleh dari hasil analisis data penelitian pada Mutu Sekolah di SMK menggambarkan hasil ratarata sebesar 4,63 yang berada pada kategori sangat tinggi. Hal tersebut tergambar dari skor rata-rata dimensi Mutu Kurikulum sebesar 5.00, Mutu peserta didik sebesar 4.32, Mutu Pendidik sebesar 4.70, Lingkungan kerja sebesar 4.84, disiplin sekolah sebesar 4.56, ketersediaan sumber belajar sebesar 4.56, partisipasi orang tua sebesar 4,72 dan satuan biaya sebesar 4.72 .

Skor rata-rata dimensi mutu kurikulum lebih tinggi dari pada dimensi lainnya. Sedangkan dimensi yang terendah adalah mutu peserta didik. Hal ini menggambarkan 
bahwa kecenderungan mutu kurikulum di SMK telah sesuai dengan yang kurikulum yang dibuat telah mengacu pada kurikulum pusat, serta kurikulum yang dikembangkan disekolah sudah sesuai dengan kebijakan pemerintah.

Berdasarkan hasil analisis korelasi, diperoleh nilai $p$ value $=0,000$. Nilai $P$ value tersebut kurang dari taraf signifikasi 0,05. Hal ini berarti hipotesis yang menyatakan bahwa terdapat pengaruh manajemen pembiayaan pendidikan terhadap mutu sekolah "Diterima" karena signifikan.

Berdasarkan perhitungan diperoleh korelasi antara mananjemen pembiayaan pendidikan terhadap mutu sekolah sebesar $\mathrm{r}=0,766$ Setelah melihat koefesien korelasi maka pengaruh manajemen pembiayaan pendidikan terhadap mutu sekolah menunjukkan korelasi kuat. Dapat disimpulkan dari hasil korelasi tersebut terdapat pengaruh yang positif mengenai manajemen pembiayaan pendidikan terhadap mutu sekolah di SMK.

Dari hasil analisis korelasi kemudian didukung oleh hasil analisis koefesien determinasi yang menggambarkan besarnya pengaruh manajemen pembiayaan pendidikan terhadap mutu sekolah pada SMK di Kota Bandung sebesar 58,7\% sedangkan $41,3 \%$ dipengaruhi oleh faktor lain seperti kurikulum, manajemen sekolah, fasilitas, guru, peserta didik, masyarakat, dan kultur sekolah (Ali. M, 2007. hlm 361).

Sedangkan untuk mengetahui signifikasi korelasi antar variabel $\mathrm{X}$ dengan variabel $\mathrm{Y}$ dengan membandingkan antara $t_{\text {hitung }}$ dengan $\mathrm{t}_{\text {tabel }}$ berdasarkan perhitungan SPSS 17.00 diketahui thitung 6,525 sedangkan ttabel dengan dk-2 (32-2=30) adalah 1,697. Dengan demikian menunjukkan $\mathrm{t}_{\text {hitung }}$ lebih besar dari $\mathrm{t}_{\text {tabel }}(6,525>1,697)$. Artinya terdapat pengaruh yang signifikan antara manajemen pembiayaan pendidikan dengan mutu sekolah. Pengaruh manajemen pembiayaan pendidikan terhadap mutu sekolah ditunjukkan dalam persamaan:

$$
\widehat{\mathbf{Y}}=35,905+0,754 X 1
$$

Harga 35,905 merupakan nilai konstanta yang menunjukkan bahwa jika tidak ada keterlibatan sama sekali dari manajemen pembiayaan pendidikan, maka mutu sekolah sebesar 35,905, sedangkan harga 0,754 merupakan regresi yang menunjukkan bahwa setiap adanya kenaikan manajemen pembiayaan pendidikan sebesar 1, maka akan ada kenaikan nilai mutu sekolah sebesar 0,754. Dan setiap adanya kenaikan manajemen pembiayaan pendidikan 10, maka akan diikuti kenaikan mutu sekolah sebesar 7,54.

Dengan adanya temuan tersebut, terbukti bahwa manajemen pembiayaan pendidikan secara signifikan memberikan pengaruh terhadap mutu sekolah pada SMK di Kota Bandung. Menurut hasil perhitungan analisis koefesien determinasi, manajemen pembiayaan pendidikan terhadap mutu sekolah sebesar 58,7\%. Artinya manajemen pembiayaan pendidikan yang lebih tinggi kemungkinan dapat memberikan sumbangan yang lebih besar dari 58,7\% terhadap peningkatan mutu sekolah pada SMK di Kota Bandung.

Biaya dan mutu sekolah mempunyai keterkaitan secara langsung. Menurut (Morphet, 1983), “biaya pendidikan memberikan pengaruh yang positif melalui faktor kepemimpinan dan manajemen pendidikan dan tenaga pendidikan yang kompeten dalam meningkatkan pelayanan pendidikan melalui peningkatan mutu." 
Dalam menunjang peningkatan mutu sekolah di SMK, manajemen pembiayaan pendidikan diharapkan mampu memenuhi kebutuhan pendidikan sehingga menunjang peningkatan mutu sekolah. Berdasarkan penelitian pada 32 sekolah dengan sumber pembiayaan dari dana BOS memiliki mutu sekolah yang kecenderungan rata-ratanya sangat tinggi. Hal tersebut membuktikan bahwa untuk menyelenggarakan pendidikan diperlukan peran serta pembiayaan pendidikan. Dana penyelenggaraan berbasis masyarakat dapat bersumber dari penyelenggara, masyarakat, pemerintah pusat, pemerintah daerah dan sumber lain yang tidak bertentangan dengan peraturan perundang-undangan yang berlaku.

Sekolah dengan sumber pendanaan dari pemerintah mengharuskan kepala sekolah untuk mampu menjalankan tugas manajerialnya dalam bidang keuangan. Manajemen pembiayaan mengupayakan perencanaan, pelaksanaan, pengawasan dan evaluasi bagi setiap kegiatan pembelajaran dari sektor pembiayaan. Pemahaman terhadap tahapan manajemen pembiayaan diperlukan sekali karena dengan pengelolaan pembiayaan yang efektif dan efisien, setiap kegiatan pembelajaran mampu ditunjang keberhasilannya, sehingga mutu sekolah dapat ditingkatkan.

\section{SIMPULAN}

Mutu Sekolah di SMK berada pada kategori sangat tinggi. hal ini berarti bahwa kurikulum, mutu peserta didik/ siswa, mutu pendidik, lingkungan kerja disiplin sekolah, ketersediaan belajat, partisipasi orang tua, satuan biaya sudah berada pada kategori sangat tinggi. Dimana hal tersebut didukung oleh partisipasi masyarakat sekitar yang lebih banyak memilih sekolah negeri atau sekolah swasta dengan bantuan dana dari pemerintah dengan alasan pembiayaan.

Berdasarkan hasil tersebut, dimensi mutu peserta didik memperoleh nilai rata-rata sebesar 4,32 hal ini terjadi karena indikator pada dimensi ini yakni hasil ujian pada beberapa SMK masih belum memenuhi standar, selain itu pula angka putus sekolah masih tinggi dengan alasan yang beragam salah satunya adalah karena tidak ada biaya untuk membayar sekolah dan ada juga siswa yang drop-out serta diatas 5\% peserta didik setiap tahunnya tidak dapat lulus. Jika yang dibanding dengan scor lainnya scor pada dimensi mutu peserta didik masih tergolong rendah.

Manajemen pembiayaan pendidikan di SMK berada pada kategori sangat tinggi, artinya kepala sekolah pada SMK telah mampu melaksanakan manajemen pembiayaan pendidikan secara maksimal mulai dari perencanaan pembiayaan dan penganggaran, implementasi pembiayaan, pengawasan dan pengendalian pembiayaan dan pertanggung jawaban atau akuntabilitas. Kecenderungan pada ke-empat dimensi ini maka diperoleh nilai terendah yakni pada dimensi implementasi pelaksanaan pembiayaan. Hal ini terjadi salah satunya karena kurangnya peran serta orang tua siswa atau masyarakat baik dari sumbangan materil, tenaga, maupun dalam pelibatan pengambilan keputusan untuk programprogram sekolah.

Pengaruh yang diberikan oleh manajemen pembiayaan pendidikan terhadap mutu pendidikan di SMK berada pada kategori kuat. Hal tersebut membuktikan bahwa dengan manajemen pembiayaan yang baik, maka akan mampu meningkatkan 
mutu sekolah. Rata-rata kecenderungan manajemen pembiayan terhadap mutu pendidikan di SMK sudah pada kategori yang sangat baik pada tahap perencanaan sampai pertanggung jawab pembiayaan. Meskipun pada pelaksanaannya di lapang masih belum sesuai dengan pencapaian standar nasional pendidikan. Hal tersebut terbukti dengan penggunaan anggaran yang sesuai dari setiap alokasi yang diberikan pemerintah, serta kesesuaian dengan perencanaan yang dibuat oleh sekolah dalam bentuk RKAS. Namun, beberapa kendala membuktikan masih perlu ditingkatkannya kembali pada tahapan implementasi pembiayaan pendidikan sehingga apa yang telah direncanakan menjadi pedoman dalam implemantasinya. Hal tersebut akan berpengaruh terhadap pencapaian mutu pendidikan sebagai tujuan sekolah.

\section{DAFTAR RUJUKAN}

Fattah, N. (2009). Ekonomi dan Pembiayaan Pendidikan. Bandung: PT: Remaja Rosdakarya.

Hoy, W. K., \& Miskel, C. G. (2008). Educational Administration; Theory. Research, and Practice. New York: McGraw-Hill Csmpions.

Morphet, E. . (1983). The Economic and Financing of Education, Fourth Edition. New Jersey: Prenticce Hall Inc.

Republika. (2015). Data Badan Pusat Statistik tentang tingkat pengangguran. Retrieved from http://www.republika. co.id/berita/ekonomi/makro/15/11/05/nxbwv9383-jumlah-pengangguran-di-indonesia-bertambah-320ribu-orang

Santoso, \& Budi. (2014). Pengaruh Kepemimpinan Kepala Sekolah, Kinerja Mengajar Guru, Pengelolaan Fasilitas Pembelajaran, dan Proses Pembelajaran Terhadap Mutu Kompetensi Lulusan Smk Bidang Keahlian Manajemen dan Bisnis Di Kota Bandung. Universitas Pendidikan Indonesia. 